J. Clin. Chem. Clin. Biochem.

Vol. 19, 1981, pp. 465-469

\title{
Synthesis in Vitro of Glycosaminoglycans in Regenerating Rat Liver
}

\author{
By A. M. Gressner, J. E. Cadenbach and H. Greiling
}

Department of Clinical Chemistry and Pathobiochemistry of the Medical Faculty of the Technical University (RWTH) Aachen, FRG

(Received December 1, 1980)

Summary: Chronic liver damage is accompanied by both liver cell multiplication and stimulated synthesis of proteoglycans, but the relationship between the two biochemical processes has not been investigated so far. We found that the incorporation of $\left[{ }^{14} \mathrm{C}\right]$ glucosamine into total glycosaminoglycans of rat liver slices from regenerating tissue is depressed by about $50 \% 1$ and 3 days after operation if referred to that measured in sham-operated control liver slices. $6 \mathrm{~h}$ after partial hepatectomy $\left[{ }^{14} \mathrm{C}\right]$ glucosamine incorporation into glycosaminoglycans is stimulated by more than $30 \%$ in relation to sham operated livers. The proportional rates of synthesis of heparan sulfate and chondroitin sulfate (about 8:1) did not change in regenerating liver tissue. Furthermore, there was no difference in the intracellular uptake of $\left[{ }^{14} \mathrm{C}\right]$ glucosamine by rat liver slices from sham operated and partially hepatectomized rats; the pool size of UDP-N-acetylhexosamine was only slightly larger (about $14 \%$ ) under the latter experimental condition. We conclude that liver regeneration by itself is not responsible for the elevated production and the changing pattern of proteoglycans in long-lasting hepatic injury.

\section{Die in vitro Biosynthese der Glykosaminoglykane in der regenerierenden Rattenleber}

Zusammenfassung: Chronische Leberschädigungen werden begleitet sowohl von Leberzellregeneration als auch stimulierter Synthese von Proteoglykanen, aber die Beziehung zwischen beiden biochemischen Prozessen ist bis jetzt nicht untersucht worden. Wir stellten fest, daß die Inkorporation von $\left[{ }^{14} \mathrm{C}\right]$ Glucosamin in die gesamten Glykosaminoglykane der Rattenleberschnitte von regenerierendem Gewebe 1 und 3 Tage nach der Operation um etwa 50\% gehemmt ist, wenn die Einbaurate mit der in Explantaten von scheinoperierten Rattenlebern verglichen wird. $6 \mathrm{~h}$ nach partieller Hepatektomie ist die $\left[{ }^{14} \mathrm{C}\right]$ Glucosamin-Einbaurate, verglichen mit schein-operierten Tieren, um mehr als $30 \%$ erhöht. Die relativen Syntheseraten von Heparansulfat und Chondroitinsulfat (etwa 8:1) verändern sich nicht im regenerierenden Lebergewebe. Uberdies ließ sich kein Unterschied in der intrażellulären Aufnahme von $\left[{ }^{14} \mathrm{C}\right]$ Glucosamin in Rattenleberschnitten von scheinoperierten und partiell hepatektomierten Ratten feststellen; die Poolgröße von UDP-N-Acetylhexosaminen war nur geringfügig größer (etwa 14\%) unter der letztgenannten experimentellen Bedingung. Wir schließen aus den Ergebnissen, daß die Leberregeneration selbst nicht für die erhöhte Biosynthese und das verändẹte Muster der Proteoglykane in der langzeitig geschädigten Leber verantwortlich ist.

\section{Introduction}

The transition of hepatocytes from the normal, non-proliferative state to active growth increases the biosynthesis of various macromolecules such as DNA, RNA, and proteins (1-5). Cell proliferation in liver can be induced, most commonly, by partial hepatectomy (6) or by injection of papain $(7,8)$, infusion of TAGH solution $\left.{ }^{1}\right)(9)$, and by a shift in the protein content in the food of the animal (10). For human pathology, however, the induc-

1) TAGH solution contains: Triiodothyronine, Glucagon, Amino acids, Heparin. tion of hepatocellular multiplication as a consequence of liver cell necrosis caused by either chemical, nutritive, or infectious hepatotoxins is of great significance. In fact, the stimulus (i) for liver cell mitosis in chemically damaged livers seems to be quite similar (if not identical) to that (those) operating in the remnant liver after surgical intervention (11). Hepatic regeneration is a well known histologic symptom of chronically injured livers, which, in addition, are frequently associated with a considerable accumulation of the components of the intercellular matrix leading to liver fibrosis and cirrhosis (12-14). It is believed, that the pathogenesis of liver fibrosis involves an active synthesis of 
proteoglycans (15-18) and collagens (19-21) in injured liver but the stimulatory mechanisms are not understood. In particular, it is not known whether there is a causal link between increased synthesis of glycosaminoglycans in injured liver and hepatic regeneration, i.e. whether the activation of glycosaminoglycan synthesis is a biochemical feature of the pleiotypic response of the actively dividing liver tissue (22). In an attempt to answer this question we studied the synthesis of sulfated glycosaminoglycans in liver explants prepared from the regenerating tissue, in which the factors of cell necrosis and consecutive inflammation, associated with most models of experimental hepatic fibrosis, are excluded.

\section{Materials and Methods}

\section{Materials}

$D-\left[1-{ }^{14} \mathrm{C}\right]$ glucosamine hydrochloride $(291.6 \mathrm{GBq} / \mathrm{ml}=7.88 \mathrm{Ci} /$ $\mathrm{mol})$ and UDP-N-acetyl-D-[1-14 $\mathrm{C}]$ glucosamine (1.976 Bq/ $\mathrm{mol}=53.4 \mathrm{Ci} / \mathrm{mol}$ ) were obtained from New England Nuclear Corp., Boston, USA; the commercial sources and specifications of chondroitin $\mathrm{AC}$ lyases (EC 4.2.2.5), chondroitin $\mathrm{ABC}$ lyases (EC 4.2.2.4), streptococcal hyaluronate lyases (EC 4.2.2.1), papain (EC 3.4.22.2) and of unlabelled glycosaminoglycans were as described previously (15).

\section{Partial hepatectomy}

Male Sprague-Dawley rats, weighing 180-250 g were fed ad libitum with a standard rat diet and kept in a room with a constant temperature $\left(25^{\circ} \mathrm{C}\right)$ and a $12 \mathrm{~h}$ light-darkness cycle. Partial hepatectomy was carried out between 9 and 12 a.m. under ether anesthesia by the method of Higgins \& Anderson (6). About $70 \%$ of the hepatic lobes was usually removed. Sham-operated rats were treated similarly except that the liver was replaced in the abdomen after being exposed for about $20 \mathrm{~s}$

\section{Preparation and incubation of liver slices}

Rats were killed by decapitation between 9 and 11 a.m., except those animals sacrificed $6 \mathrm{~h}$ after operation, and their livers quickly removed, chilled and rinsed in ice-cold phosphate buffered saline. Slices of $0.5 \mathrm{~mm}$ thickness (about $100 \mathrm{mg}$ wet weight) were prepared manually and incubated for $6 \mathrm{~h}$ at $37^{\circ} \mathrm{C}$ under $5 \% \mathrm{CO}_{2}-95 \% \mathrm{O}_{2}$ in $3 \mathrm{ml}$ of Dulbecco's modification of Eagles medium (pH 7.4) containing $135 \mathrm{kBq}(5 \mu \mathrm{Ci})$ of $D$ $\left[1^{-14} \mathrm{C}\right]$ glucosamine hydrochloride and supplemented with $4 \mathrm{mmol} / \mathrm{l}$ of $L$-glutamine and $44 \mathrm{mmol} / \mathrm{l}$ of $\mathrm{NaHCO}_{3}$ (15).

\section{Quantitation of the incorporation of $\left[{ }^{14} \mathrm{C} \mid\right.$ hexosamine into total and specific types of liver glycosaminoglycans}

At the end of incubation liver slices were transferred into cold acetone, delipidized and proteolyzed according to the procedure described previously (15). Total glycosaminoglycans were precipitated with cetylpyridinium chloride, their radioactivity measured and referred to the protein content (23) of the liver explant.

The radioactivity incorporated into specific types of glycosaminoglycans was quantitated by enzymatic degradation of total glycosaminoglycans with chondroitin $\mathrm{ABC}$ lyases (chondroitin sulfate and dermatan sulfate), chondroitin $\mathrm{AC}$ lyases (chondroitin sulfate), and hyaluronate lyases (hyaluronic acid), by degradation with nitrous acid (heparan sulfate and heparin), and by anionexchange chromatographic procedures (keratan sulfate-like fraction) as detailed elsewhere (15).
Determination of the pool size of UDP-N.acetylhexosamines in normal and regenerating liver

Immediately after decapitation the liver was transferred into $50 \mathrm{ml}$ of icecold $0.75 \mathrm{~mol} / 1$ perchloric acid and homogenized (15). The homogenate, from which an aliquot was taken for the determination of the concentration of protein (23), was centrifuged and the neutralized supernatant applied to a Dowex $1 \mathrm{X} 8$ column $(0.7 \times 12 \mathrm{~cm})$. The nucleotide sugars eluted with $0.4 \mathrm{~mol} / \mathrm{l}$ of ammonium formate, $\mathrm{pH} 4.5$ (24) were chromatographed on Whatman $3 \mathrm{MM}$ paper (2'5). The area cochromatographing with authentic UDP-N-acetyl-D: $\left[1-{ }^{14} \mathrm{C}\right]$ glucosamine was excised from the paper and eluted with water. The absorbance at $260 \mathrm{~nm}$ of the eluate was measured and the concentration determined by use of a standard curve containing known amounts of UDP-N-acetylglucosamine. The total amount of UDP-N-acetylhexosamines was referred to liver protein (23).

Determination of the intracellular uptake of $\mathrm{I}^{14} \mathrm{Cl}$ glucosamine by cells in liver explants

After incubation the slices were washed extensively with ice-cold phosphate-buffered saline containing $5 \mathrm{mmol} / \mathrm{l}$ unlabeled glucosamine and homogenized in $2 \mathrm{ml}$ of cold water (15). The homogenate was treated with $60 \mathrm{~g} / \mathrm{l}$ trichloroacetic acid for $1 \mathrm{~h}$ at $0^{\circ} \mathrm{C}$; after centrifugation the radioactivity of the supernatant was measured (15).

Statistic analysis

The t-test for independent samples was applied (26).

\section{Results}

In comparison with sham-operated and non-treated livers the incorporation of $\left[{ }^{14} \mathrm{C}\right]$ glucosamine into total glycosaminoglycans of slices from regenerating liver is depressed by more than $40 \% 1$ and 3 days after partial hepatectomy. $6 \mathrm{~h}$ after partial liver resection the incorporation of the labeled amino sugar into glycosaminoglycans is similar to that of unoperated rat livers but significantly higher than that measured in sham-operated livers $6 \mathrm{~h}$ after operation (tab. 1).

Nearly $90 \%$ of the label was found in the nitrous acid labile fraction identified previously as heparan sulfate (15), the remainder was degradable by chondroitin AC lyase and, hence, represents chondroitin sulfate. In accordance with published data (15) no incorporation of the amino sugar into dermatan sulfate was detectable, and less than $1 \%$ of the total glycosaminoglycan associated radioactivity was localized in hyaluronic acid and a keratan sulfate-like fraction. The relative rates of synthesis of hepatic heparan sulfate and chondroitin sulfate did not change $6 \mathrm{~h}, 1 \mathrm{~d}$, and $3 \mathrm{~d}$ after partial liver resection and were not different from those measured in slices from sham-operated livers (tab. 2).

In order to exclude differences in the uptake of $\left[{ }^{14} \mathrm{C}\right]$ glucosamine into cells of liver slices from regenerating and sham-operated livers their acid-soluble, intracellular radioactivity was determined at various times of incubation. It is shown in table 3 that during incubation the amount of radioactivity is similar for both types of liver slices thus ruling out impaired absorption of $\left[{ }^{14} \mathrm{C}\right]$ - 
Tab. 1. The synthesis of total glycosaminoglycans in regenerating, sham-operated and non-operated rat liver. Slices prepared from the livers $6 \mathrm{~h}, 1 \mathrm{~d}$, and $3 \mathrm{~d}$ after operation were incubated for $6 \mathrm{~h}$ in medium containing $\left[{ }^{14} \mathrm{C}\right.$ glucosamine. Total glycosaminoglycans were isolated and their radioactivity (mean value \pm S.D.) determined. The number of rats analysed is given in parenthesis. For $1 \mathrm{~d}$ after operation the incorporation into the glycosaminoglycans of the regenerating liver tissue is corrected for the pool size of UDP-N-acetylhexosamine (tab. 4). The values are given in square brackets.

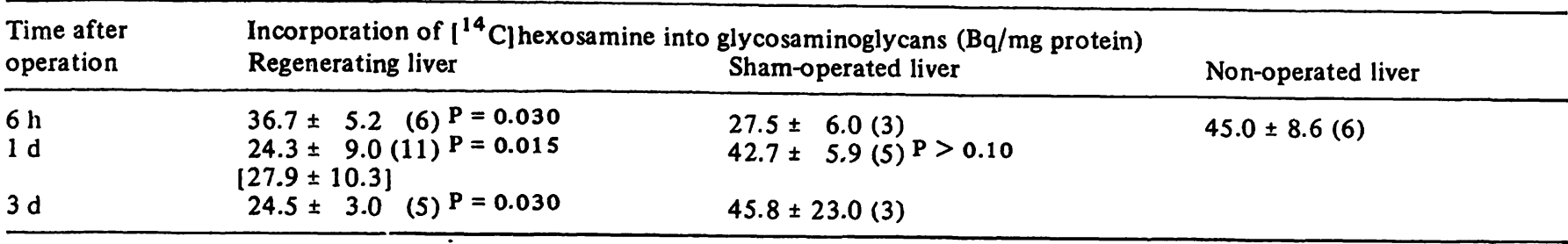

Tab. 2. The proportional rates of synthesis of specific types of hepatic glycosaminoglycans in regenerating and sham-operated rat liver. Liver slices prepared from rats sacrificed $6 \mathrm{~h}, 1 \mathrm{~d}$, and $3 \mathrm{~d}$ after partial hepatectomy and sham-operation, respectively, were incubated as described in table 1 . The incorporation of $\left[{ }^{14} \mathrm{C}\right]$ hexosamine into the various types of glycosaminoglycans is expressed as percentage of the incorporation into total glycosaminoglycans.

The number of rats analysed is given in parenthesis, the values are the mean \pm S.D.

\begin{tabular}{llllr}
\hline $\begin{array}{l}\text { Time after } \\
\text { operation }\end{array}$ & \multicolumn{2}{c}{$\begin{array}{c}\text { Percentage of total glycosaminoglycan synthesis } \\
\text { Regenerating liver }\end{array}$} & \multicolumn{2}{c}{$\begin{array}{c}\text { Sham-operated liver } \\
\text { Chondroitin sulfate }\end{array}$} \\
\hline $6 \mathrm{~h}$ & Heparan sulfate & Chondroitin sulfate & Heparan sulfate & Chond \\
\hline $\mathrm{ld}$ & $89.8 \pm 2.6(6)$ & $12.4 \pm 1.1(6)$ & $89.1 \pm 1.1(3)$ & $13.7 \pm 0.5(3)$ \\
$\mathrm{dd}$ & $87.3 \pm 4.5(11)$ & $12.0 \pm 2.5(11)$ & $90.7 \pm 2.1(5)$ & $12.8 \pm 2.8(5)$ \\
\hline
\end{tabular}

Tab. 3. Intracellular concentration of acid-soluble $\left[{ }^{14} \mathrm{C}\right]$ hexosamine in cells of slices from regenerating and shamoperated liver $1 \mathrm{~d}$ after operation.

Slices were incubated for various times in medium containing $\left[{ }^{14} \mathrm{C}\right]$ glucosamine. At the end of incubation the explants were washed free of extracellular $\left[{ }^{14} \mathrm{C}\right] \mathrm{glu}$ cosamine, homogenized, and the radioactivity in the trichloroacetic acid-soluble material was assayed. The mean values \pm S.D. of 8 determinations for each time point are listed.

\begin{tabular}{lll}
\hline $\begin{array}{l}\text { Time of } \\
\text { incubation }\end{array}$ & $\begin{array}{l}\text { Intracellular } \text { [ }^{14} \text { C]hexosamine } \\
\text { Bq/mg protein } \\
\text { Regenerating } \\
\text { liver }\end{array}$ & $\begin{array}{l}\text { Sham-operated } \\
\text { liver }\end{array}$ \\
\hline $0.5 \mathrm{~h}$ & $25 \pm 8$ & $30 \pm 8$ \\
$1 \mathrm{~h}$ & $105 \pm 20$ & $83 \pm 22$ \\
$2 \mathrm{~h}$ & $605 \pm 106$ & $635 \pm 163$ \\
$4 \mathrm{~h}$ & $665 \pm 86$ & $688 \pm 106$ \\
$6 \mathrm{~h}$ & $672 \pm 128$ & $706 \pm 183$ \\
\hline
\end{tabular}

Tab. 4. The size of the precursor (UDP-N-acetylhexosamine) pool of glycosaminoglycan synthesis in regenerating and sham-operated rat liver $1 \mathrm{~d}$ after operation. UDP-N-acetylhexosamine was isolated from the livers by a combination of ion-exchange and paper chromatographic procedures. Its absorbancy at $260 \mathrm{~nm}$ was measured and used for quantitation by means of a standard curve containing known amounts of UDP-N-acetylglucosamine. The values are the mean \pm S.D. The number of rats studied is given in parenthesis.

\begin{tabular}{ll}
\hline Treatment of rats & $\begin{array}{l}\text { UDP-N-acetylhexosamine } \\
\text { in liver } \\
\text { (nmol/mg protein) }\end{array}$ \\
\hline $\begin{array}{ll}\text { Partial hepatectomy (10) } \\
\text { Sham-operation (12) }\end{array}$ & $31 \pm 3$ \\
\hline
\end{tabular}

glucosamine by regenerating liver slices as the cause of its diminished incorporation into glycosaminoglycans.

The concentration of UDP-N-acetylhexosamine, the immediate precursor of glycosaminoglycan chain synthesis, showed a slight, but statistically significant difference in sham-operated and regenerating liver $1 \mathrm{~d}$ after operation (tab. 4). The latter contained about $15 \%$ more UDP-N-acetylhexosamine than the former. If the rate of incorporation 1 day after partial hepatectomy is corrected for the different precursor pool sizes the synthesis of hepatic glycosaminoglycans in regenerating liver tissue remains significantly reduced $(p=0.030)$ in comparison with sham-operated livers (tab. 1).

\section{Discussion}

The experiments described here demonstrate a significant depression of the incorporation of labeled glucosamine into glycosaminoglycans of regenerating liver tissue in vitro. Cellular uptake of the amino sugar did not differ in the two types of slices, the pool size of UDP-N-acetylhexosamine was only slightly larger in regenerating than in sham-operated liver tissue and the incorporation of $\left[{ }^{14} \mathrm{C}\right]$ glucosamine into UDP-Nacetylhexosamine determined under quite similar experimental conditions was reported not to be decreased (in fact increased) 6 to $48 \mathrm{~h}$ after partial hepatectomy (27). The data therefore most likely reflect diminished synthesis of hepatic glycosaminoglycans, defined as the transfer of $\mathrm{N}$-acetylhexosamine from UDP-N-acetyl- 
hexosamine into the polysaccharide chain of glycosaminoglycans. Our finding of lowered glycosaminoglycan synthesis in regenerating liver is in accordance with a similar decrease in glycoprotein synthesis in the early stages after partial hepatectomy $(27,28)$, but contrary results have also been reported (29). It is remarkable that the proportion of the synthesis of heparan sulfate and chondroitin sulfate did not change in the regenerating tissue; this indicates similar, as yet only partly understood regulatroy mechanism for both types of glycosaminoglycans. Among other factors (30) the increase in the concentration of cyclic AMP in regenerating liver tissue $(31,32)$ might control glycosaminoglycan production, since the cyclic nucleotide reduces the synthesis of both heparan sulfate and chondroitin sulfate to nearly the same extent in liver slices (33). The increase in glycosaminoglycan production in regenerating tissue in comparison with shamoperated liver $6 \mathrm{~h}$ after operation could be a consequence of the significant decrease in intracellular cyclic AMP concentration observed in the very early phase after partial hepatectomy $(31,32)$, which in turn may be caused by release of insulin in the first few minutes after operation (34). In addition, prostaglandins and thromboxane might exert some, as yet not investigated effects on the synthesis of proteoglycans in regenerating liver $(22,35)$.

Our results show that liver cell regeneration by itself does not produce an increase in glycosaminoglycan synthesis and, hence, cannot be responsible for the enhanced production of proteoglycans observed in acutely and chronically damaged liver tissue (15-18). Thus proteoglycan synthesis behaves differently from the biosynthetic pathway of collagens. The synthesis of the latter matrix molecules is stimulated in proliferating liver as indicated by the higher activity of collagen-

\section{References}

1. Bucher, N. L. R. \& Malt, R. A. (1971), Regeneration of Liver and Kidney, Little, Brown and Company, Boston.

2. Bresnick, E. (1971), in Methods in Cancer Res. (Busch, H., ed.). Vol. VI, pp. 347-397. Academic Press, New York and London

3. Becker, F. F. (1974), in The Liver: Normal and Abnormal Functions (Becker, F. F., ed.) part A, pp. 69-83. Marcel Dekker, New York.

4. Weber, G. (1975), in Liver Regeneration after Experimental Injury (Lesch, R. \& Reutter, W., eds.) pp. 103-118. Stratton Intercont. Medical Book Coop., New York.

5. Rabes, H. M. (1976), in Progress in Liver Diseases (Popper, H. \& Schaffner, F., eds.) pp. 83-99. Grune and Stratton, New York.

6. Higgins, G. M. \& Anderson, R. M. (1931), Arch. Pathol. 12, 186-202.

7. Kambara, T. \& Nohara, Y. (1966), Arch. Pathol. 81, 525-530.

8. Yamamoto, K., Omata, S., Ohnishi, T. \& Terayama, H. (1973), Cancer Res. 33, 567-572.

9. Short, J., Brown, R. F., Husakova, A., Gilbertson, J., Zemel, R. \& Lieberman, I. (1972), J. Biol. Chem. 247, 1757-1766. prolylhydroxylase in regenerating liver $(36,37)$ and in the parenchymal cells isolated from regenerating tissue (38). In addition, the typical occurrence of a trimer of $\alpha 1$ type I collagen $\left([\alpha 1(\mathrm{I})]_{3}\right)$ in cirrhotic livers (39) was proposed to be a biosynthetic product of the replicating hepatocytes $(40)$.

Obviously glycosaminoglycan synthesis and content in liver is inversely related to the proliferative tendency of the cells. In mitosis-induced liver the nuclear content of glycosaminoglycans is reduced significantly (41), the cell coat glycosaminoglycans disappear temporarily (42-44) and the mucopolysaccharides surrounding hepatoma cells differ markedly from those attached to normal liver cells $(45,46)$. Furthermore, liver tumor cells (Novikoff hepatoma) synthesize less heparan sulfate than the normal counterpart (47) and density-dependent inhibition of hepatoma cell growth in culture is restored by addition of cell coat acid mucopolysaccharides (48). The predominant role in this process is played by cell surface heparan sulfate $(45,49)$. As reported very recently $(50)$ the concentration of heparan sulfate does not change significantly in regenerating liver tissue, whereas that of chondroitin sulfate and, less marked, that of dermatan sulfate show biphasic temporal changes in the regenerating liver. From our results it appears that the timedependent changes in the concentration of glycosaminoglycans (in particular of the ratio chondroitin sulfate to dermatan sulfate) in the regenerating liver tissue cannot be explained solely on the basis of their biosynthetic rates in vitro. But it should be emphasized that hepatic glycosaminoglycan synthesis in vivo is exposed to several additional, mainly humoral factors which can affect the profile of glycosaminoglycan production and, thus, are responsible for some differences between glycosaminoglycan synthesis ex vivo (liver explants) and in vivo (liver in situ) (51).

10. Short, J., Armstrong, N. B., Zemel, R. \& Lieberman, I. (1973), Biochem. Biophys. Res. Commun. 50, 430-437.

11. Morley, C. G. \& Boyer, J. L. (1977), Biochim. Biophys. Acta 477, 165-176.

12. Popper, H. \& Udenfriend, S. (1970), Amer. J. Med. 49, 707-721.

13. Rojkind, M. \& Kershenobich, E. (1976), in Progress in Liver Diseases (Popper, H. \& Schaffner, F., eds.) Vol V, pp. 294-310. Grune and Stratton, New York.

14. Gressner, A. M. (1980), Med. Welt 31, 11-16.

15. Gressner, A. M., Pazen, H. \& Greiling, H. (1977), HoppeSeyler's Z. Physiol Chem. 358, 825=833.

16. Gressner, A. M., Pazen, H. \& Greiling, H. (1977), Experientia 33, 1290-1292.

17. Mc Gee, J. O. D., Patrick, R. S., Rodger, M. C. \& Luty, C. M. (19:74), Gut 15, 260-267.

18. Becker, K. (1967), Z. Ges. Exp. Med. 144, 222-235.

19. Rojkind, M. \& Diaz de Leon, L. (1970), Biochimi Biophys. Acta 217, 512-522.

20. Mc Gee, J. O. D. \& Patrick, R. S. (1972), Lab. Invest. 26, 429-440.

21. Chen, Th. S. N. \& Leevy, C. M. (1975), J. Láb. Clin. Med. $85,103-112$. 
22. Miura, Y. \& Fukui, N. (1976), Adv. Enzyme Regul. 14, 393-405.

23. Lowry, O. H., Rosebrough, N. J. Farr., A. L. \& Randall, R. J. (1951), J. Biol. Chem. 193, 265-275.

24. Horwitz, A. L. \& Crystal, R. G. (1975), J. Clin. Invest. 56, 1312-1318.

25. Kornfeld, S. \& Ginsburg, V. (1966), Exp. Cell Res. 41, 592-600.

26. Sachs, L. (1972), Statistische Auswertungsmethoden, 3. ed. Springer, Berlin.

27. Okamoto, Y. \& Akamatsu, N. (1977), Biochim. Biophys. Acta 498, 272-281.

28. Serafini-Cessi, F. (1976), Biochem. J. 158, 153-155.

29. Akamatsu, N., Nakajima, H. \& Miyata, S. (1976), Biochem. J. 158, 589-592.

30. Starzl, Th. E. \& Terblanche, J. (1979), in Progress in Liver Diseases (Popper, H. \& Schaffner, F., eds.) pp. 135-151 Grune and Stratton, New York.

31. Fausto, N. \& Butcher, F. R. (1976), Biochim. Biophys. Acta 428, 702-706.

32. Miura, Y., Iwai, H., Sakata, R., Ohtsuka, H., Elhanan, E., Kubota, K. \& Fukui, N. (1976), J. Biochem. (Tokyo) 80, 291-297.

33. Gressner, A. M. \& Schulz, W. unpublished observation.

34. Bucher, N. L. R. \& Swaffield, M. N. (1975), Proc. Natl. Acad. Sci. USA 72, 1157-1160.

35. Kanzaki, Y., Mahmud, I., Asanagi, M., Fukui, N. \& Miura, Y. (1979), Cell. Molec. Biol. 25, 147-152.

36. Benjamin, I. S., Than, T., Ryan, S., Rodger, M. C., McGee, J. O. \& Blumgart, L. H. (1978), Brit. J. Exp. Pathol. 59, 333-336.
37. Benjamin, I. S., Mc Gee, J. O., Than, T., Rodger, M. C. \& Blumgart, L. H. (1975), Endocrinology 95, 829.

38. Guzelian, P. S. \& Diegelmann, R. F. (1979), Exp. Cell Res. 123, 269-279.

39. Rojkind, M., Giambrone, M.-A. \& Biempica, L. (1979), Gastroenterology 76, 710-719.

40. Hata, R., Ninomiya, Y., Nagai, Y. \& Tsukada, Y. (1980), Biochemistry 19, 169-176.

41. Furukawwa, K. \& Terayama, H. (1979), Biochim. Biophys. Acta 585, 575-588.

42. Ohnishi, T., Yamamoto, K. \& Terayama, H. (1973), Histochemie 36, 15-20.

43. Ohnishi, T., Yamamoto, K. \& Terayama, H. (1973), Histochemistry 36, 1-14.

44. Miyamoto, M., Terayama, H. \& Ohnishi, T. (1973), Biochem. Biophys. Res. Commun. 55, 84-90.

45. Akasaki, M., Kawasaki, T. \& Yamashina, I. (1975), FEBS Lett. 59, 100-104.

46. Yamamoto, K. \& Terayama, H. (1973), Cancer Res. 33, 2257-2264.

47. Anghileri, L. J. (1976), Z. Krebsforsch. 85, 73-77.

48. Ohnishi, T., Ohshima, E. \& Ohtsuka, M. (1975), Exp. Cell Res. 93, 136-142.

49. Oldberg, A., Kjellén, L. \& Höök, M. (1979), J. Biol. Chem. $254,8505-8510$.

50. Edward, M., Long, W. F., Watson, H. H. K. \& Williamson, F. B. (1980), Biochem. J. 188, 769-773.

51. Gressner, A. M., Köster-Eiserfunke, W., Van de Leur, E. \& Greiling, H. (1980), J. Clin. Chem. Clin. Biochem. 18, 279-285.
Prof. Dr. A. M. Gressner

Abteilung Klinische Chemie und Pathobiochemie Klinisch-Chemisches Zentrallaboratorium der Med. Fakultät der RWTH

Goethestr. 27-29

D-5100 Aachen 
